\title{
RELIGION AND AUTHORITY: \\ THE ROLE OF RHETORIC AS THE VOICE OF MORALITY - A PROLEGOMENON
}

\author{
Yehoshua Gitay \\ Department Afro-Asiatic Studies \\ University of the Free State
}

\begin{abstract}
This paper focuses on speech as an instrument of the human organs. We don't see speech but we hear it and the words create pictures in our minds that stir our imagination. This paper deals with the effect of speech upon the hearers and discusses the role of the verbal effect known as Rhetoric, on Biblical Religion. Furthermore, the paper claims that Biblical Rhetoric, as an argumentative discourse $i$, at the end of the day, a manifestation of democracy in terms of the struggle between the proclamation of authority and the voice of human criticism that challenges the ultimate. Hence, speech is instrumental in forcing authority to explain or justify its deeds, therefore, substituting the power of authority with a matter of rational human persuasion.
\end{abstract}

Keywords: Bible, Rhetoric, Morality, Democracy

\section{The Realm of Rhetoric}

All religious systems are rhetorical because they strive to communicate truth. It argues for a distinctive rhetoric of religion, based on authoritative proclamation, not rational persuasion, with the speaker's character as dominant (O’Rourke Boyle 2001, 662).

Thus opens the article on Religion of the Encyclopedia of Rhetoric, maintaining that authoritative proclamation determines the nature of Religious rhetoric and as such, religious systems call for a distinctive rhetoric rather than persuasion by reason (the human way). The premise is that Religion and reason are not harmonized. However, in the context of the Hebrew Bible, the question to be asked is - in light of the authoritative approach to religious rhetoric - how to deal with specific Biblical texts where God responds to human criticism regarding His justice. Abraham's claim that God's decision to destroy the population of two cities was not justified in accordance with human criteria of justice is a case to be considered:

And the Lord said, because the cry of Sodom and Gomorrah is great... And Abraham drew near and said, Wilt thou also destroy the righteous with the wicked? Peradventure there be fifty righteous within the city: Wilt thou also destroy and not spare the place for the fifty that are therein?... Shall not the judge of all the earth do right? And the Lord said, if I find in Sodom fifty righteous within the city, then I will spare all the place for their sakes (Gen 18:23-26).

A chain of questions that is repeated five more times follows this plea. Each of which is fully answered by God as Abraham argues in terms of the principle of quality versus quantity as the criterion of justice that might affect God's decision. Abraham continues to argue, reducing the number of potential righteous to ten. God nevertheless responds that even this small number of righteous people does not exist. Consequently, God's punish- 
ment has been justified in terms of Abraham's reasoning. That is to say, God's determination to destroy the place with its people is not a matter of authority but a traumatic decision which is assessed and argued between humankind and God in accordance with human reasoning. The debate between Abraham and God, between the "dominant character' and a human being might be defined as a verbal argument (rather than authoritative proclamation) that falls into the realm of Rhetoric.

What is Rhetoric actually? In referring to Rhetoric as an argumentative endeavor we need to make a distinction between logic and argument. Logic is a conclusion about truth and the justification of its acceptance. Logic is without appeal: Its propositions are true. However, argumentation, which also deals with propositions, that is, truth-values, is no more than a substitute, appropriate in nonscientific contexts. A preposition is the point of departure of an argument, which is Rhetoric. Rhetoric works with the conflict between propositions that truth is not convincing "as such" (cf. Meyer 1994, 67-68).

God's proclamation that He intends to destroy the two cities, Sodom and Gomorrah, is not taken by Abraham as an entirely conclusive conclusion, which is a truth in itself. Rather, Abraham regards it as a proposition, which is a point of departure for argument. That is, Abraham's verbal performance is, in fact, a rhetorical endeavor, an act of argumentation that is not distinctive but falls into the realm of the art of Rhetoric. In other words, the debate between Abraham and God is performed according to the rules of human persuasion rather than a distinctive (Religious) Rhetoric. Hence, the present essay questions the definition of authoritative proclamation as the essence of (Hebrew) Biblical Rhetoric.

Therefore, this paper discusses Rhetoric as a process of argumentation that seeks to present God's values not "as such," but through an act of reasoning regarding God's truthvalues. For the sake of demonstration attention is given to three specific utterances: God's responses to Job, Jonah and Abraham regarding the matter of the truth-values of His conduct that are not convincing "as such." These three human beings question God's morality or (one may dare to say) God's integrity and in a sense His authority. God replies through dramatic Rhetorical speeches that seek to persuade. The fact that God argues His case points out that there is a tension between God's act as a demon and God who acts rationally and morally - according to human moral terms when Rhetoric is instrumental in presenting God's acts morally and rationally. Thus, God's authority is not conceived through His Rhetoric - only as a matter of "fear and trembling," but above all as a moral authority, which must be presented according to human moral perception. God finds it necessary to appeal to people in order to justify His moral conduct in their terms. Thus, two partners participate in an argumentative endeavor when the inferior questions the moral motivation of the superior through dynamic Rhetoric.

\section{The Language of Communication and Argumentation between God and the People}

God Himself rather than His agents justifies His deeds through an appeal to reason. But how does God reason; in His peculiar language? Are human beings capable of perceiving God's reasoning as an act of persuasion rather than a proclamation of authority? The point is that the process of communication between God and human kind through a linguistic medium is not something that can be taken for granted. Nevertheless, the concept of communication between God and human beings is based on a fundamental hermeneutical principle that has been introduced through Mediaeval Jewish and Christian exegesis of the Bible. The presupposition is that the Torah spoke as in human language, Scriptura humane loquitur. That is to say, God's verbal revelation is adjusted to the human ability to under- 
stand Him. This leading principle of communication has been understood by the great Sephradic Jewish commentator Ibn Ezra (1092-1164) to mean that the Torah adjusted itself to the conventional human perception (cf. Funkenstein 1991, 72-81). This hermeneutical principle enables human beings to perceive God's word (and argumentation) in their language. Thus, God's word as well as His will guide us in our understanding of the role of Rhetoric regarding the Scriptures.

\section{The Question of God's Authority and its Limitations}

God's authority (in terms of "the power or a right to command, enforce obedience," [Webster Dictionary]) is demonstrated to human beings through the account of creation; as the creator of human beings $\mathrm{He}$ is the authority. The meaning of this creation of the human beings in God's image is that human kind possesses a little power than God: "For you have made him a little power than Elohim" (Ps 8:6) referring, in fact, to the human unique power of speech as the creators of new realities or new situations in their lives through their verbal skill. This human skill is correlated to the notion of the Biblical world regarding the word as a power of creation as Gen 1 and Ps 29 might demonstrate. The act of creation is a speech endeavor:

Then God said: Let there be light; and there was light. (Gen 1:3, and see vv. 9, 11, 14, 20, $24,26)$

The voice of the Lord is over the waters; the God of glory thunders, the Lord over mighty waters. The voice of the Lord is powerful; the voice of the Lord is full of majesty. (Ps 29:3)

In any event, it is important to note that the first utilization of God's authority regarding His relationship to Adam, the first human being, conveys authority as the following command demonstrates:

Of every tree of the garden you might freely eat. But of the tree of the knowledge of good and evil, you shall not eat of it, for in the day that you eat thereof you shall surely die. (Gen $2: 16-17)$

God's communication with Adam constitutes two elements: (1) a command and (2) a threat. However, the threat implies that in spite of God's authority Adam might refuse to obey God. The ability to decline God's authority is Adam's privilege that constitutes, in fact, the major difference between nature, animals and human beings. Nature is created exactly as humans through the word, which carries a creative power. But only human beings have the ability and the power to disobey God's word. Thus, human beings are creatures that given their freedom or independency, have forced God to add a further element to the command - referring to their potential disobedience, which is a threat. Furthermore, in addition to the threat God might seek to affect people through a personal promise, which reflects the addressee's personal wish. Abraham's situation is demonstrative as he is promised to be a father of a nation (Gen 12:3). However, Abraham is childless, thus, the promise might be his last chance of fatherhood (Gen 12:1-3 compared to Gen 11:30). The promise might motivate him - rather than God's command itself - to follow in God's steps. That is to say, God's authority is unquestionable but there is - for the human being - a way to refuse Him. Still, human beings may reject God's authority and choose their own way, but that might not imply that they reason with Him in order to change His conduct (see Eve and Adam who do not really argue with God regarding their punishment).

In this regard, we might ask whether the people of the Bible are in Prometheus' situation as Aeschylus ends his horrible tragedy regarding the tyrannical power of the gods: See how I suffer, how unjust this is. 
In the dramatic present of the Prometheus Bound, Zeus' government of the universe is represented as despotism of the most brutal kind. (Herington 1975, 11)

Aeschylus reaches the conception of supreme Tyrant, the enemy of man. Ruling the world, and of champion of mankind, standing up against him. (Murray 1968, 56)

Does the God of Adam control His subjects only through threats and punishment (or awards) with no real sense of true dialogue between Him and His human subjects? In other words, is there no act of persuasion as an appeal to human reasoning or self understanding in order that the person will be persuaded by God - not just as a result of command or fear of threat, or a fulfillment of self-interest in light of what seems to be impossible by the course of nature?

Actually, as rhetoric demonstrates the Biblical situation is not paralleled to that of Prometheus'. The Prophets communicate God's will to His people, reasoning with the audience through vivid Rhetoric. However, here the act of communication is not taking place by God Himself but through His messengers the prophets.

God Himself communicates directly to certain individuals by means of dialogue which is a rhetorical endeavor. The cases of Job, Jonah and Abraham might demonstrate God's rhetoric when He replies to specific inquiries regarding the meaning of His deeds and through His responses seek to justify Himself.

\section{Rhetoric and Morality}

What is the meaning of God's reasoning with human beings in terms of His authority? The point is that when God seeks to appeal to His human addressees, He actually shares with them His concerns, expecting them to accept His authority in light of His reasoning.

The act of reasoning, which is in fact, participation with the authority's decision making, might be seen as an exercise of "democracy" in the context of religious authority. At first glance, one might claim that Democracy and religious authority are not well harmonized and such a comparison has certain limitations as there are principles that are non-negotiable for the religious authority (Berger 2004, 77-78). However, the following definition of Democracy (formulated by the Chair of the International Panel on Democracy and Development [IPDD]) may work for us as a guideline for the inclusion of democracy in the realm of religious authority. We read:

[Democracy is] a system whereby the whole society can participate ... in the decision making process and keep control over it ... democracy can be defined as a political system that is capable of correcting its own dysfunctions. (Boutros-Ghali 2003, 7-8)

The democratic principles revolve around participation and control in the process of decision making. In this regard, Biblical Rhetoric plays a significant role in the act of "democratizing" the religious authority. Thus, the prophet Isaiah, seeking to justify God's punishment - given the people's moral misbehavior - calls for a debate with God, that is, the religious authority. Therefore, the prophet encourages the community not just to participate in the decision making (punishment) but, in fact, to control God's decision to punish through their reasoning. Thus says Isaiah:

Come now, and let us reason together, says the Lord.

Though your sins are like scarlet,

They shall be as white as snow; (1:18),

לכו נא ונוכחה יאמר ה': אם יהיו חטאיכם כשנים כשלג ילבינו...

The style here is distinctive as the particle "let us" softens the command "go." The audience is invited to consider the issue rather than been forced to accept it (Gitay 1991, 33). In other 
words, the audience - if succeeded in their argument - might change God's decision as the red color will turn to be white. This is the height of God's relationship with the people in terms of participating and controlling God's decision. Isaiah seeks to present God's authority, not through the manifestation of His superiority and the exercise of His authority as such, but through reasoning. Thus, God's authority is not autocratic but a subject of human criticism that might influence God to correct His decision. Therefore, God's verbal reasoning with His subordinates democratized His ultimate authority as $\mathrm{He}$ is not above criticism and $\mathrm{He}$ is open to share His reasoning and be persuaded that He misjudged the case. Rhetoric is instrumental in democratizing the religious authority.

In this regard, we need to remind ourselves about the place of Rhetoric in the course of the human struggle to free the power of magic, the irrational. In midst $5^{\text {th }}$ century B.C.E. the Greek Sophists introduced a new intellectual dimension to human culture. Mythos is replaced by Logos. "The aristocracy of the myths was losing its authority to a democracy of public arguments" (Poulakos 1995, 13). The high achievement of the Greek Sophists is the secularization of human thought, which is the replacement of magic by reasoning.

Thus, when human beings reason with God we can take it almost as an act of democracy (a term which in this context is preferable to "secularization"), that is, a reflection of a debate between people transferred to the highest religious sphere. This is the case of the Greeks when the Sophists who developed the art and technique of verbal persuasion replaced the religious means of communication through the power of irrational techniques (e.g., Delphi) that rejected reasoning. In this respect, God's speeches in the (Hebrew) Bible are based on human rhetoric in terms of reasoning and might be looked at in terms of the rhetorical principles of logic, common sense, the absurd, and the rhetorical question also manifested through the transformation to prose when the myth is in poetry (cf. Gitay 1993, 192-202). Rhetoric is therefore the means of manifesting God's democratization, which contrasts the communicative medium of the mysterious that manifests God's power - the numinous.

Thus, God's speeches in the Hebrew Bible function to ensure that His will is not demonic. In this respect, God's rhetoric is harmonized with the matter of His moralization. Thus, the readers of the horrified account of Isaac binding are told in advance that the Akkedah, the extraordinary trial of Human submission to God through the horrible sacrifice of a son, is not a manifestation of the numen, but is actually a trial, therefore justifying the event moralistically:

And it came to pass after these things, that God put Abraham to the test. He said to him: Abraham ... take your son, your favored one, Isaac, whom you love, and go to the land of Moriah, and offer him there as a burnt offering... (Gen 22:1-2).

The announcement that is conveyed to the readers (but not to Abraham!) is designed to soften the impact of the horrible request for the shocked reader who might be traumatized by such a terrible request. This is also the situation regarding Job as we are told in advance that his suffering is not a goal in itself but is actually a trial (Job 1-2).

Furthermore, the phenomenon of God who reasons is paralleled to the development of the Hebrew Religion. In terms of the history of Religions, Rudolf Otto revealed in Biblical monotheism a moralistic dimension, which substitutes the demonic conception. Thus, Otto $(1969,75)$ proposes in his monumental work "The Idea of Holy" that:

The venerable religion of Moses marks the beginning of a process which from that point onward ... charged with ethical import, until it becomes the "holy" in the full sense of the word. The culmination of the process is found in the Prophets and the Gospels. And it is in this that the special nobility of the religion revealed to us by the Bible is to be found. 
Nevertheless, the process of the "moralization of the idea of God' is so prevailing that Otto $(1969,111)$ warns his readers that this idea of God's moralization "is not a god substitute but rather the completion and charging of it with a new content."

In parallel, what Otto has observed as an historian of Biblical Religion regarding God's moralization, Rhetoric demonstrates the idea in terms of God's reasoning. Biblical rhetoric is therefore the literary-linguistic manifestation of reasoning in human perception, which is a true reflection of the democratization of Biblical religion in respond to human criticism.

\section{God's Reasoning}

Rhetoric is therefore the foundation of critical thinking, which is the core of democracy and moralization as well. Rhetoric functions to enable the society to participate in decision making, referring in our case to the realm of religious authority.

As a rule, God Himself does not address the entire community but rather individuals, and not under abstract situations but rather in crises. For the sake of demonstration we can think about Jonah, Job and Abraham as individuals who challenged God's morality and received His argued response. Thus, in all three cases God's behavior is under question. Why does God not punish the cruelest enemy of Israel (Jonah)? Why does God torture His most devoted servant (Job)? Why is God ready to destroy righteous people just because they are surrounded by the wicked (Abraham)? Here, God's morality is at stake. Therefore, His reasoning is instrumental in justifying His behavior in human terms.

Thus, the argument that takes place between Jonah and God is fundamental in democratizing His authority. Jonah's behavior is strictly anti-Rhetoric. He does not talk to God but runs away. His utterance to the people of Nineveh is deliberatively brief (only five words, Jonah 3:4) - lacking any rhetorical appeal (Gitay 1995, 197-206). However, after Jonah accuses God of distorting the proper historical course of punishing the evil (Jonah 4:1-3) God speaks to him. When Jonah prays to God, blaming God for being too merciful (Jonah 4:2), God explains His reasons for being tolerant and not exercising Jonah's sense of justice in terms of revenge. God appeals, employing human reasoning (Jonah 4:10-11), as the goal is to persuade Jonah (and the readers) rather than to perpetuate God's decision as such. Here, God seeks persuasion through the rhetorical means of the analogy:

Yahweh replied: You are only upset about a castor-oil plant which cost you no labor, which you did not make grow, which sprouted in a night and has perished in a night. And am I not to feel sorry for Nineveh, the great city, in which there are more than a hundred and twenty thousand people who cannot tell their right hand from their left, to say nothing of all animals? (Jonah 4:10-11)

This is Rhetoric par excellence as there is no mystery in God's response. The analogy to the castor-oil plant that protected Jonah from the terrible heat and now had been disappeared is illuminating as a matter of self-explanatory. However, God explains through an analogy that intends to demonstrate in human perception the unexplained, transferring the known to the unknown - through comparison that has as its purpose the clarification, structuring and evaluation of the theme in terms of what one knows (Perelman 1982, 114125). God's authority (ethos) was established through His reasoning that democratized His authority rather than forced His authority as such.

Nevertheless, Otto's $(1969,75)$ warning that God's moralization is not His substitute is applied to His rhetoric as well in terms of its democratization. Rhetoric does not substitute God's authority but is "charging it with a new content." Thus, God responds to Job's request: "I will ask and you will inform me" (Job 42:4). His reply is through a chain of rhetorical questions that Job is incapable of responding appropriately, such as: 
Where were you when I laid the earth's foundation...

Who decided the dimensions of it, do you know? (Job 38:4-5)

Indeed, Job is presented as a limited human being but as human, he is capable of asking difficult questions and can receive answers which are designed to explain to him why he is incapable of understanding - rather than merely have his inquiries ignored his inquiries (cf. Gitay 1999, 1-12). That is to say, Job challenged God to appear before him and to answer his questions, and indeed God spoke to him. Thus, Job was able to assess his criticism of God through His rhetoric, rather than merely victimized (see also Habel 1985, 579).

\section{Concluding Remarks}

Heidegger (1971, 189-191) opened his lecture on Language as follows:

Man speaks ... we are always speaking ... we speak because speaking is natural to us ... only speech enables man to be the living being he is as man. Language belongs to the closest neighborhood of man's being...

On the tenth of August 1784 Hamann wrote to Herder:

If I were eloquent as Demosthenes I would yet have to do nothing more than repeat a single word three times: Reason is language, logos.

Indeed, Biblical rhetoric reveals that reason is language. And as people always speak, God speaks to them in language. Consequently, Biblical rhetoric is not distinctive but is Rhetoric in human language and reasoning. Furthermore, reason (language) is the vehicle of moralization and democratization because Rhetoric (reason, language) forces the religious authority to justify His deeds. By doing so humans might assess God's morality and participate actively in His decision-making.

The fact that God's deeds are explained by Himself in human terms of cogency (in contrast, say, to Zeus) enlightens a specific dimension of biblical religion, referred to as the democratization of God's image. God's justification is carried through His speeches designed for specific human beings who ask Him for a moral explanation for His deeds. God explains His reasons through the medium of language, reason, that is, Rhetoric.

\section{BIBLIOGRAPHY}

Berger, PL 2004. Christianity and Democracy: The Global Picture. Journal of Democracy 15:77-81.

Boutros-Ghali, B 2003. The Interaction between Democracy and Development. Paris: Unesco.

Funkenstein, A 1991. Perceptions of Jewish History from the Antiquity to the Present. Tel Aviv: Am Oved (Hebrew).

Gitay, Y 1999 The Failure of Argumentation in the Book of Job: Humanistic Language versus Religious Language. Journal of North West Semitic Languages 25:1-12. 1995 Jonah's Anti-Rhetoric. Pages 197-206 in Fortunate the Eye that Sees: Essays in Honor of David Noel Freedman. Edited by AB Beck, AH Bartlet, PR Raabe and CA Franke. Grand Rapids: William B Eerdmans Publishing Company. 1993. WF Albright and the Question of Early Hebrew Poetry. Pages 192-202 in History and Interpretation: Essays in Honor of John H Hayes. Edited by M.P. Graham. Sheffield: Sheffield University Press. 
1991. Isaiah and his Audience. Assen: Van Gorcum.

Habel, NC 1985. The Book of Job. Philadelphia: Westminster John Knox Press.

Heidegger, M 1971. Poetry, Language, Thought. New York: Harper \& Raw.

Herington, CJH 1975. Pages 3-22 in Aeschylus. Prometheus Bound. Translated by J Scully and CJH Herington. Edited by CJH Herington. Oxford: Oxford University.

Meyer, M 1994. Rhetoric, Language and Reason. University Park: The Pennsylvania State University.

Murray, G 1968. Prometheus and Job. Pages 56-65 in The Book of Job. Edited by PS Sanders. Englewood Cliffs: Prentice-Hall.

O'rourke Boyle, M 2001. Religion. Pages 662-672 in Encyclopedia of Rhetoric. Edited by TO Sloane. Oxford: Oxford University Press.

Otto, R 1969. The Idea of the Holy. London: Oxford University Press.

Perelman, Ch 1982. The Realm of Rhetoric. Notre Dame: Notre Dame University.

Poulakos, J 1995. Sophistical Rhetoric in Classical Greece. Columbia: University of South Carolina. 